\title{
INFLUENCE OF LEAD ON GROWTH AND PHYSIOLOGICAL CHARACTERISTICS OF A FRESHWATER GREEN ALGA CHLORELLA SP.
}

\author{
*Ming-Li Teoh ${ }^{1}$ and Siu-Wan Wong ${ }^{1}$
}

School of Biosciences, Taylor's University, Taylor's Lakeside Campus, No 1, Jalan Taylor's, 47500 Subang Jaya, Selangor Darul Ehsan, Malaysia.

*Correspondence Author: MingLi.Teoh@taylors.edu.my

Tel. +603 5629 5091, Fax: +6035629 5455,

Received: $13^{\text {th }}$ December $2017 \quad$ Revised: $18^{\text {th }}$ October 2018

Accepted: 28th October 2018

DOI: https://doi.org/10.22452/mjs.vol37no2.1

\begin{abstract}
Pollution caused by heavy metals poses a serious challenge to ecosystems. Microalgae are microscopic algae that form the base of the food chain in aquatic ecosystems. Heavy metals present in soils can leach into aquatic ecosystems, leading to bioaccumulation by organisms through the food chain, and exerting toxic effects on microalgae, the primary producers. This study reports the response of the alga Chlorella sp. to lead stress over experimental exposures of 11 days. Chlorella sp. were grown and exposed to different lead concentrations $(0,10,25,50,75$ and $100 \mathrm{mg} / \mathrm{L})$ at $18^{\circ} \mathrm{C}$. The experiments were conducted in triplicate. Growth rate of microalgae was determined by measuring the optical density at $620 \mathrm{~nm}\left(\mathrm{OD}_{620}\right)$ and chl- $a$ concentration. The data obtained showed that lead affects the physiological characteristics (growth, chl- $a$ and carotenoids) and protein content of Chlorella sp. Exposure to increasing lead concentrations resulted in decreasing specific growth rate $(\mu)$, chlorophyll- $a$, carotenoid and protein contents. However, the data obtained indicate that Chlorella sp. can tolerate the toxicity of lead even at high concentration.
\end{abstract}

Keywords: Chlorella, heavy metals, lead, specific growth rate, protein

\begin{abstract}
ABSTRAK Pencemaran yang disebabkan oleh logam berat menimbulkan cabaran serius terhadap ekosistem. Microalga adalah alga mikroskopik yang membentuk asas rantaian makanan dalam ekosistem akuatik. Logam berat yang terdapat di dalam tanah boleh meluap ke dalam ekosistem akuatik, yang membawa kepada bioakumulasi oleh organisma melalui rantai makanan, dan menghasilkan kesan toksik pada mikroalga, pengeluar utama rantaian makanan. Kajian ini melaporkan tindak balas alga Chlorella sp. terhadap tekanan plumbum pada pendedahan eksperimen selama 11 hari. Chlorella sp. telah dikultur dan didedahkan kepada kepekatan plumbum yang berbeza $(0,10,25,50,75$ and $100 \mathrm{mg} / \mathrm{L})$ pada suhu $18^{\circ} \mathrm{C}$. Eksperimen ini dijalankan dalam triplikasi. Kadar pertumbuhan mikroalga ditentukan dengan mengukur kepadatan optik pada $620 \mathrm{~nm}\left(\mathrm{OD}_{620}\right)$ dan kepekatan klorofil- $a$. Data yang diperolehi menunjukkan bahawa plumbum mempengaruhi ciri-ciri fisiologi (pertumbuhan, klorofil- $a$ dan karotenoid) dan kandungan protein Chlorella sp. Pendedahan kepada peningkatan kepekatan plumbum mengakibatkan penurunan kadar pertumbuhan spesifik $(\mu)$, klorofil- $a$, karotenoid dan kandungan protein. Walau bagaimanapun, data yang diperolehi menunjukkan bahawa Chlorella sp. mampu bertoleransi terhadap ketoksikan plumbum walaupun pada kepekatan tinggi.
\end{abstract}

Kata kunci: Chlorella, logam berat, plumbum, kadar pertumbuhan spesifik, protin 


\section{INTRODUCTION}

Heavy metal pollution is a serious environmental issue that is harming natural ecosystems and human health. Heavy metals can enter the environment through air, soil or water. Increasing amounts of heavy metals have been released into estuarine ecosystems over the last century (Jung, 2017; Penuelas \& Filella, 2002; Nriagu \& Pacyna, 1988). Lead, cadmium and mercury are examples of non-essential heavy metals that can cause harm to living organisms even at low concentration. Heavy metals such as zinc and copper are essential micronutrients for living organisms. However, toxicity occurs when the concentration of a particular metal ion in the environment exceeds a specific threshold level. Industrial wastes and urban wastes that contain heavy metals are often released into rivers and coastal regions leading to aquatic pollution (Jung, 2017; Wang et al., 2007).

Heavy metal-containing
compounds cannot be degraded by
microorganisms, unlike many organic compounds. When these heavy metals are converted into stable and permanent pollutants, build-up in soils and sediments will occur (McComb et al., 2014). These heavy metals can cause adverse effects to organisms living in aquatic ecosystems as they enter the food chain and bioaccumulation takes place through successive trophic levels. When heavy metals accumulate in marine biota such as fish and other marine animals, they can then be consumed by humans or domestic animals (through feed), with harmful consequences to human or animal health (McComb et al., 2014; Shanab et al., 2012; Kong et al., 1995).

Lead is a toxic heavy metal that occurs naturally in the Earth's crust. The natural levels of lead in soil range between 0.5 and 10 ppm (USEPA, 2003). This metal is extensively used in industrial applications such as batteries and paints (Yun et al., 2011). Lead may enter the environment from these past and current uses and resulted in substantial increases in lead levels in the environment. Lead from anthropogenic sources may result in concentrations exceeding $10,000 \mathrm{ppm}$ (USEPA, 2003). Individuals working near lead mining, smelting and construction locations are particularly exposed to lead as it can enter the human body through ingestion and inhalation. When the blood lead levels exceeds $25 \mu \mathrm{g} / \mathrm{dL}$, this causes adverse effects such as neurological damage and chronic nephropathy (Mason et al., 2014; Papanikolaou et al., 2005). Lead can cause severe harm to aquatic life even at low concentration of $10 \mathrm{ppm}$ (Kaplan, 2013). It exerts toxic effects by forming ligands with other metabolites, competing with other metabolites by binding to functional groups, or by replacing other metals with the same ionic charges causing changes in enzymatic activities and disruption of cellular processes (BáscikRemisiewicz et al., 2009; Awad et al., 2005).

Microalgae are diverse organisms that have rapid growth rates and productivity and are able to live in harsh conditions due to their unicellular or simple multicellular structure (Li et al., 2008a, b). Microalgae are the primary producers at the base of the aquatic food chain and are the first organisms affected by heavy metal pollution. Microalgae are commonly used as biosensors in environmental analyses and monitoring due to their high sensitivity and specificity in detecting heavy metal pollutants (Mata et al., 2009; Védrine et al., 2003). Studies have shown that microalgae possess extracellular and intracellular mechanisms to resist metal toxicity (Scheidegger et al., 2011; Perales-Vela et al., 2006), including the ability to absorb a certain amount of heavy metals. Heavy metals are able to enter algal cells via active transport or endocytosis, with help from 
chelating proteins such as phytochelatin and class II metallothioneins thus, reducing heavy metal toxicity. These chelating proteins form complexes with heavy metals and transfer them to intracellular vacuoles (Perales-Vela et al., 2006). However, toxicity occurs when the amount of heavy metals taken up exceeds a critical concentration. The binding of heavy metal ions to sulphydryl groups in the protein cysteine, disruption of protein structure or displacement of essential elements will, eventually, affect the physiological and biochemical processes of the microalgae (Arunakumara \& Zhang, 2008).

Chlorella contains important biochemical components such as chlorophyll- $a$ (chl- $a$ ), carotenoids, proteins, lipids and carbohydrates. These green algae are consumed by humans as health supplements in the form of tablets, liquid extracts or powder. Species of Chlorella are also commonly used to assess the responses of aquatic ecosystems to heavy metal pollution by providing essential information on the toxic effects of specific heavy metals on metabolic processes (Sears, 2013). In this study, Chlorella was chosen as a model to conduct toxicity testing due to its rapid growth rate and productivity, high sensitivity to various heavy metals, and high ability to adapt to different environmental conditions (Carfagna et al., 2011; Li et al., 2008a, b; Nyholm \& Kallqvist, 1989).

The aim of this study was to measure growth, chl- $a$ concentration, carotenoid and protein content of Chlorella sp. exposed to different lead concentrations $(0,10,25,50,75$ and $100 \mathrm{mg} / \mathrm{L})$ over an 11 days experimental period. The percentage of inhibition of lead in Chlorella sp. was also determined.

\section{MATERIALS AND METHODS}

\section{Algal Culture}

A culture of Chlorella sp. (152069) was purchased from Carolina Biological Supply Company (USA). This was sub-cultured in Bold's Basal Medium (BBM) and maintained in a temperature-controlled growth chamber (Protech Growth Chamber, Tech-Lab Scientific Sdn. Bhd., Malaysia) set at $18^{\circ} \mathrm{C}$. Illumination was provided by cool fluorescent lamps (42 $\mu \mathrm{mol} / \mathrm{m}^{2} / \mathrm{s}$ ) with 12-12 light-dark cycles.

\section{Experimental Design}

A stock solution of $1000 \mathrm{mg} / \mathrm{L} \mathrm{Pb}$ (II) was prepared by dissolving $\mathrm{Pb}\left(\mathrm{NO}_{2}\right)_{3}$ in distilled water and filter sterilization. The working solutions were diluted to the desired concentrations during the experiments. At a constant temperature of $18^{\circ} \mathrm{C}$, triplicate flasks containing algal cultures were exposed to different lead concentrations $(0,10,25,50,75$, and 100 $\mathrm{mg} / \mathrm{L}$ ) for 11 days (stationary phase) to study their growth responses, chl- $a$, carotenoid, and protein content.

\section{Growth Measurements}

The inoculum (10 \%) used was from exponential phase cultures standardized at an optical density at $620 \mathrm{~nm}\left(\mathrm{OD}_{620}\right)$ of 0.2 . The algal cultures were grown in $500 \mathrm{~mL}$ flasks and were exposed to different lead concentrations as described above. The cultures were sampled on day $0,2,4,7,9$ and 11 to determine growth rate. Two parameters were used to monitor growth of cultures, $\mathrm{OD}_{620}$ and chl- $a$ concentration. The latter was measured using a spectrophotometric method after extraction of the filtered cells (glass-fibre filters, 0.45 $\mu \mathrm{m}$ ) in acetone (Parsons \& Strickland, 
1963). Specific growth rate $\left(\mu, d^{-1}\right)$ based on $\mathrm{OD}_{620}$ was calculated using the following formula:

$$
\mu\left(d^{-1}\right)=\left(\operatorname{Ln~N} N_{2}-\operatorname{Ln~N}_{1}\right) /\left(\mathrm{t}_{2}-\mathrm{t}_{1}\right)
$$

Where $\mathrm{N}_{2}$ is $\mathrm{OD}_{620}$ at $\mathrm{t}_{2}, \mathrm{~N}_{1}$ is $\mathrm{OD}_{620}$ at $\mathrm{t}_{1}$, and $t_{2}$ and $t_{1}$ are times within the exponential phase. The cells were harvested at the end of the experiment by filtration for determination of the protein content.

\section{Protein Analysis}

Proteins were extracted in $0.5 \mathrm{~N} \mathrm{NaOH}$ $\left(80^{\circ} \mathrm{C}, 30 \mathrm{~min}\right)$ and the concentration determined by the dye-binding method (Bradford, 1976).

\section{Percentage of Inhibition}

The following equation was used to calculate the percentage of inhibition based on specific growth rate $(\mu)$ of the control and treatments.

$$
I_{\mu i}=\frac{\mu_{c}-\mu_{i}}{\mu_{c}} \times 100 \%
$$

Where $I_{\mu i}=$ Percentage of inhibition for test concentration $i, \mu_{i}=$ Mean specific growth rate for test concentration $i$ and $\mu_{c}=$ Mean specific growth rate for test concentration $i$.

\section{Statistical Analyses}

IBM SPSS Statistics 20.0 was used to conduct statistical analysis. Analysis of Variance (ANOVA) was used to test for overall differences between treatments, followed if significant by pairwise Tukey comparisons. The different concentration of lead was used as the independent variable while specific growth rate, final chl- $a$ concentration, carotenoid, protein and percentage of inhibition were used as dependent variables. Differences were considered significant at $\mathrm{p}<0.05$.

\section{RESULTS}

\section{Growth Trends}

Based on the specific growth rate $(\mu)$, a decreasing trend in $\mu$ was observed as the concentration of lead increased from 0 $\mathrm{mg} / \mathrm{L}$ to $100 \mathrm{mg} / \mathrm{L}$ (Figure 1 ). The cultures grown under control condition $(0 \mathrm{mg} / \mathrm{L}$ lead) exhibited the highest $\mu(0.286 \pm 0.003$ $\mathrm{d}^{-1}$ ) while those exposed to $100 \mathrm{mg} / \mathrm{L}$ showed the lowest $\mu\left(0.257 \pm 0.003 \mathrm{~d}^{-1}\right)$. The $\mu$ of control and lead concentration of $10 \mathrm{mg} / \mathrm{L}$ did not differ significantly. Although there was a limited but significant decrease in growth with increasing lead concentrations, the algae could clearly tolerate and grow at all the lead concentrations tested over the 11 days duration of the experiment. 


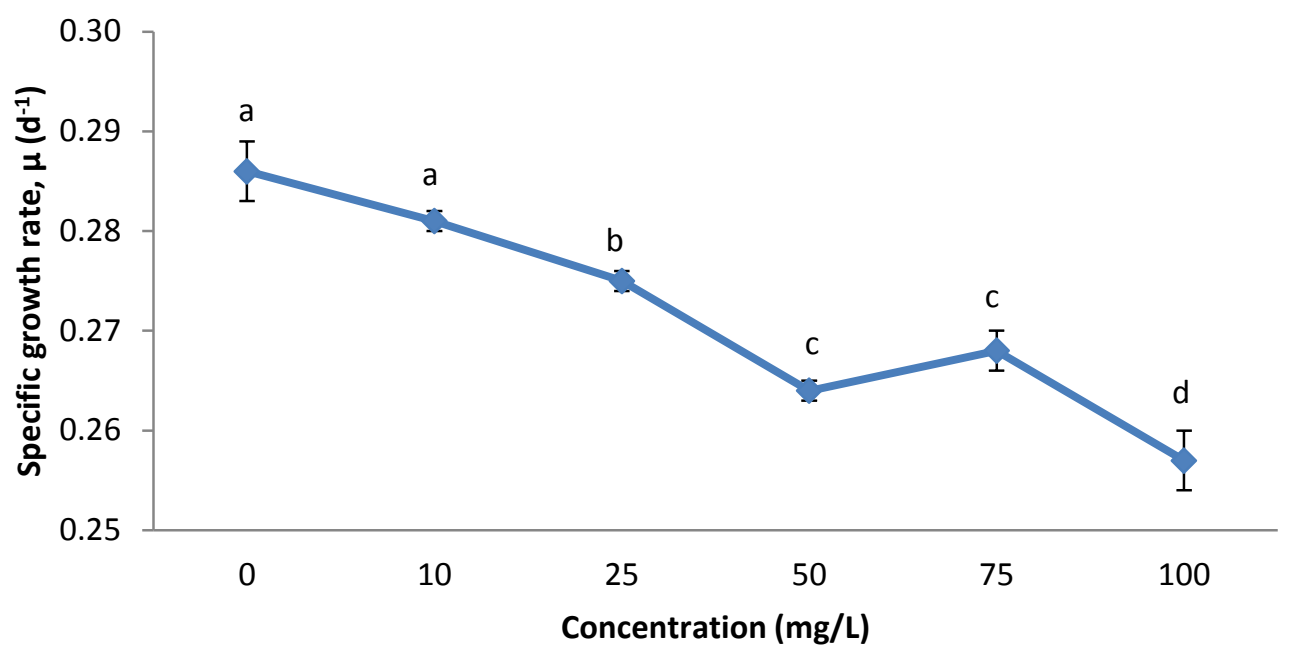

Figure 1: Specific growth rate $\left(\mu, \mathrm{d}^{-1}\right)$ based on $\mathrm{OD}_{620}$ of Chlorella sp. grown at different lead concentrations. Data represent mean values of triplicate cultures and error bars are standard deviations. Different letters indicate significant differences at $\mathrm{p}<0.05$.

\section{Final Chl-a and Carotenoid Contents}

Lead concentrations of $0 \mathrm{mg} / \mathrm{L}$ (control) led to the highest final chl- $a$ concentration $(16.07 \pm 0.74 \mathrm{mg} / \mathrm{g} \mathrm{DW})$ while the highest lead concentration of $100 \mathrm{mg} / \mathrm{L}$ caused a marked decreased $(64.28 \%)$ in final chl- $a$ concentration $(5.74 \pm 0.25 \mathrm{mg} / \mathrm{g} \mathrm{DW})$
(Figure 2). A decreasing trend in the final chl- $a$ concentration was clear as the lead concentration increased. A similar but less strong pattern was apparent in carotenoid content, with the highest content in the control $(0.72 \pm 0.08 \mu \mathrm{g} / \mathrm{mL})$ and the lowest at a lead concentration of $100 \mathrm{mg} / \mathrm{L}(0.57 \pm$ $0.03 \mu \mathrm{g} / \mathrm{mL})$.

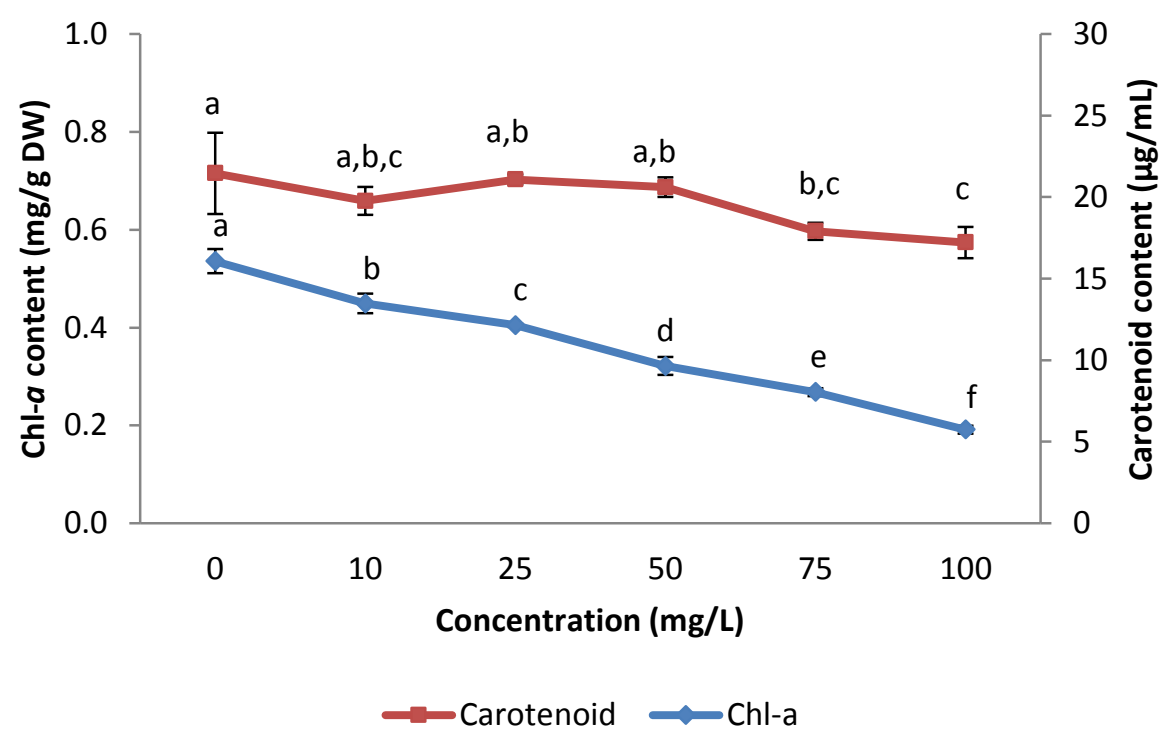

Figure 2: Final chl- $a$ and carotenoid contents of Chlorella sp. grown at different lead concentrations. Data represent mean values of triplicate cultures and error bars are standard deviations. Different letters indicate significant differences at $\mathrm{p}<0.05$. 


\section{Protein Content}

Cultures grown at zero or low lead concentrations $(0,10,25 \mathrm{mg} / \mathrm{L})$ showed similar protein content, significantly greater (c. $40 \%$ ) than those grown at lead concentrations of 50,75 and $100 \mathrm{mg} / \mathrm{L}$ (Figure 3).

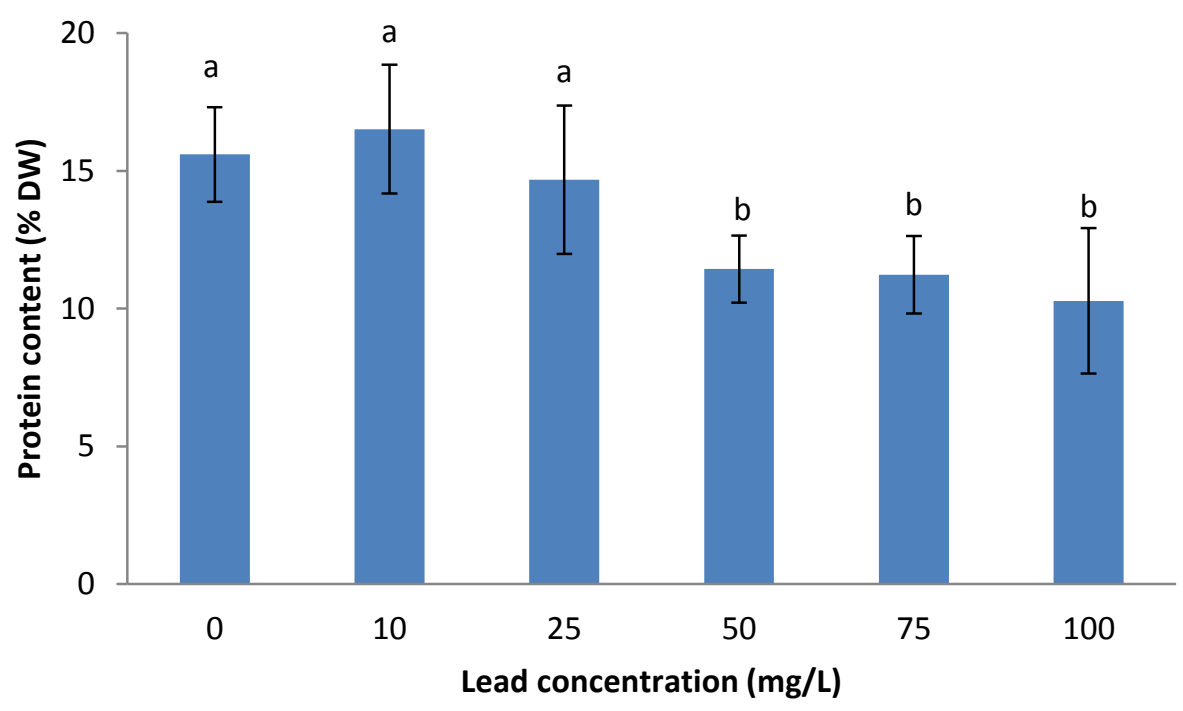

Figure 3: Protein content (\% DW) of Chlorella sp. grown at different lead concentrations. Data represent mean values of triplicate cultures and error bars are standard deviations. Different letters indicate significant differences at $\mathrm{p}<0.05$.

\section{Percentage of Inhibition of Growth}

Percentage of inhibition of growth rate of Chlorella sp. grown at different lead concentrations is shown in Figure 4. All lead concentrations to some extent inhibited growth, varying between only slight inhibitions $(1.75 \%)$ at $10 \mathrm{mg} / \mathrm{L}$ to $10.14 \%$ at $100 \mathrm{mg} / \mathrm{L}$.

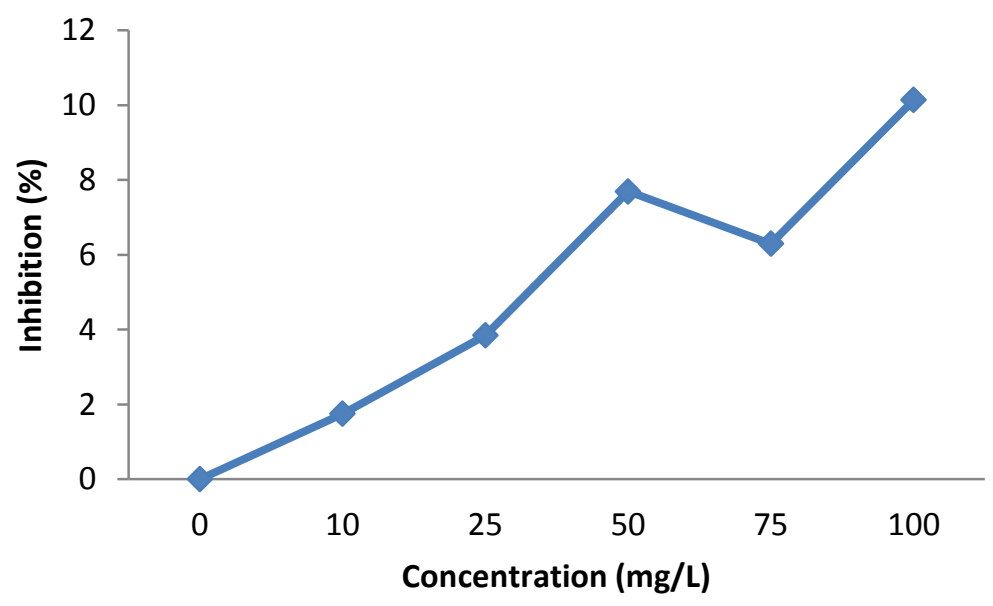

Figure 4: Percentage of inhibition of growth of Chlorella sp. grown at different lead concentrations. 


\section{DISCUSSION}

Specific growth rate $(\mu)$ is used to determine the ability of microalgae growth in lead-influenced environments. Here, cultures grown under the highest lead concentration $(100 \mathrm{mg} / \mathrm{L})$ had the lowest $\mu$, consistent with other studies that have reported that the $\mu$ of Chlorella sorokiniana (Carfagna et al., 2013), C. vulgaris and $C$. protothecoides (Zhang et al., 2013) declined with exposure to increasing lead concentration.

Our data indicate that the Chlorella sp. strain examined is able to tolerate the toxicity of lead even at higher concentration $(100 \mathrm{mg} / \mathrm{L})$. Other algae such as Phormidium ambiguum, Pseudochlorococcum typicum and Scenedesmus quadricauda var. quadrispina are also able to tolerate lead concentrations up to $100 \mathrm{mg} / \mathrm{L}$ (Shanab et al., 2012). This may be due to a variety of mechanisms possessed by microalgae to maintain metal homeostasis and prevent toxicity. At intracellular level, heavy metals may enter cells through micronutrient transporters, with accumulation inside the cells being via active processes. Once within the cell, they can bind to peptides or polyphosphate bodies to form organometallic complexes. The synthesis of peptides including phytochelatins and class II metallothioneins can be enhanced by metal ions such as $\mathrm{Cd}^{2+}$ and $\mathrm{Pb}^{2+}$ (Kaplan, 2013; Perales-Vela et al., 2006). Sulphide ions $\left(S^{2-}\right)$ that can also be present in the organometallic complex will also help in stabilizing the complex, enhancing the detoxification effect. The organometallic complex may then be transported to specific cellular compartments such as vacuoles to help in controlling the cytoplasmic concentration of heavy metal ions and, thereby, protect against their toxicity (Kaplan, 2013; Perales-Vela et al., 2006).
A high concentration of heavy metal ions can exert a great impact on physiological functions of algae such as growth and cell division (Wang \& Chen, 2009). The reduction in growth rate of Chlorella sp. at highest lead concentration examined (100 mg/L; Figure 1) might be due to interaction of the metal ion with the fat layer on the cell surface of microalgae at extracellular level (Chu \& Hashim, 2007). On the surface of microalgae cells, there are a number of functional groups exposed such as $-\mathrm{NH}_{2},-\mathrm{COO}^{-}$and $-\mathrm{SH}$, that function as metal binding sites (Kumar et al., 2014). Heavy metal ions binding to these sites can then pass through the cell membrane to enter the cytoplasm (Kumar et al., 2014). This can cause disruption to the microalgal intracellular structure as well as disrupting physiological and biochemical processes (Kumar et al., 2014; Al-Hejuje, 2008).

When algal cells are exposed to lead, this results in reduced energy supply as well as negative impacts on intracellular enzyme systems such as lipase and cellulose (Sander \& Murthy, 2009; Awasthi $\&$ Das, 2005). These effects can depress the rate of cell division or cause damage to the cell membrane. Cell membrane damage can lead to uncontrollable influx or efflux of electrolytes or vital ions leading to either an excess or a deficiency in the cytoplasm, affecting growth (Awasthi \& Das, 2005).

Chlorophyll is the most important pigment in microalgae cells, key to absorbing the solar energy required for photosynthesis. In this study, exposure to $100 \mathrm{mg} / \mathrm{L}$ lead concentration resulted in an approximately $64 \%$ reduction in chl- $a$ concentration (Figure 2). Other studies have shown that increasing lead concentration result in decreased rates of photosynthesis associated with declining of chl- $a$ concentrations in Chlorella species (Zhang et al., 2013; Shanab et al., 2012). When microalgae are exposed to lead, the 
metal ion's oxidative potential causes inhibition of key enzymes that play a crucial role in the $\mathrm{CO}_{2}$-fixation cycle. Any decrease in the activity of these essential enzymes will reduce ATP synthesis in $\mathrm{CO}_{2}$ fixation, where ATP and NADPH are primary requirements for $\mathrm{CO}_{2}$-fixation. Reduction in ATP synthesis will reduce the production of ATP and NADPH and thus, impact the photosynthetic rate (Muwafq \& Bernd, 2006; Awasthi \& Das, 2005).

Exposure to heavy metals influences the electron transfer systems in mitochondria and chloroplasts. This will hinder the electron flow on both the acceptor and donor side of PSII, affecting the biochemical processes involved in photosynthesis (Al-Hejuje, 2008). Moreover, it can be assumed that exposure to heavy metals may lead to substitution or impairing of the uptake of important elements for photosynthetic pigments such as magnesium and potassium. Disruption of cation exchange will cause alteration of chloroplast ultrastructure and lead to damage of thylakoid membranes and reaction centres (Dao \& Beardall, 2016; Carfagna et al., 2013), affecting the light harvesting pigments. Transformation of shape and organization of thylakoids indicates damage to the photosynthetic apparatus, leading to inhibition of PSII and a decrease in the chlorophyll content and chlorophyll $a / b$ ratio (Neelam \& Rai, 2003). A recent study by Dao \& Beardall (2016) also reported that lead affected both the reaction centres and the antennae of Chlorella and Scenedesmus, and therefore impacted negatively on their PSII activity and caused alterations in PSII heterogeneity.

\footnotetext{
Carotenoids are light-harvesting pigments that possess antioxidant properties that suppress triplet state chlorophyll molecules, quench toxic free radicals and help to restore physiological balance. The total carotenoid content of Chlorella sp. under the treatments imposed
}

in the current study showed a similar pattern to the final chl- $a$ concentration (Figure 2). Cultures grown at the highest lead concentration $(100 \mathrm{mg} / \mathrm{L})$ generated a slightly lower carotenoid level $(0.57 \pm 0.03$ $\mu \mathrm{g} / \mathrm{mL}$ ) compared to other concentrations. Similar findings have also been reported in another species (Oscillatoria boryana), which showed decreasing carotenoid content when exposed to increasing concentration of heavy metals (Priyadarshani \& Rath, 2012). However, the absolute impact of lead on carotenoid content was not large. Other studies have reported that Chlorophyceae such as Chlorella and Scenedemus are able to accumulate carotenoids such as canthaxanthin and astaxanthin under stressful conditions (Guedes et al., 2011; Takaichi, 2011).

Exposure to heavy metals can result in intermittent intracellular oxidative stress conditions resulting from the accumulation of reactive oxygen species (ROS) (Mittler, 2002; Pinto et al., 2003). When microalgae are exposed to stressful conditions, they synthesize additional secondary carotenoids via carotenogenesis (Faraloni \& Torzillo, 2017; Lemoine \& Schoefs, 2010). Oxidative stress induced by heavy metal exposure has been demonstrated to affect astaxanthin synthesis (Takaichi, 2011). Astaxanthin could play a crucial role in responding to stress in microalgae, as accumulation of astaxanthin is assumed to be a defensive reaction to stress, protecting the microalgae against oxidative damage (Gao et al., 2013; Guedes et al., 2011).

Cultures grown at zero or low lead concentrations produced the highest percentage of protein content (Figure 3). High lead concentrations slightly but significantly decreased the protein content of the microalgae, as also reported by Carfagna et al. (2013). Proteins within microalgal cells are used as an emergency source of nitrogen and sulphur to promote cell growth (Carfagna et al., 2013). It is also 
assumed that any limitation of sulphur availability will reduce protein biosynthesis. Ultimately this may cause failure of microalgae to perform photosynthesis in the reaction centre protein of PSII in the thylakoid membrane, affecting the growth and chl- $a$ concentration of microalgae (Pandey et al., 2013). In addition, the inability of Chlorella sp. to accumulate proteins after exposure to high lead concentration might be caused by acute oxidative stress induced by heavy metal excess in cells (Bajguz, 2011; Arunakumara \& Zhang, 2008).

The data obtained in the current study demonstrate that the strain of Chlorella sp. studied was capable of tolerating high lead concentrations of at least $100 \mathrm{mg} / \mathrm{L}$ with only limited reduction in performance over an 11 days exposure period. We suggest that various mechanisms by which microalgae are known to mitigate the effects of heavy metal stress, such as binding of metal ions to peptides and sites located on the surface of microalgal cells, were important in this resistance. Given the potential of Chlorella sp. in bioremediation, more detailed studies should be conducted including different parameters such as $\mathrm{pH}$ and temperature to understand the detailed mechanisms of heavy metal regulation in these microalgae. Furthermore, computational approaches such as docking simulation or dynamics simulation can be added to further substantiate the response of microalgae at the molecular level (Brautigam et al., 2011).

\section{ACKNOWLEDGEMENTS}

This project is supported by the School of Biosciences, Taylor's University under its Final Year Project Programme. We thank Prof. Dr. Peter Convey for comments which helped to strengthen the manuscript.

\section{REFERENCES}

Al-Hejuje M.M. (2008). Effect of some heavy metals ions on the chlorophyll a pigment of Nostoc linkia and Hapalosiphon aureus. Marsh Bulletin 3: 136-146.

Arunakumara K.K.I.U. \& Zhang X.C. (2008). Heavy metal bioaccumulation and toxicity with special reference to microalgae. Journal of Ocean University of China 7: 60-64.

Awad S., Chu T.C., Lustigman B.K. \& Lee L.H. (2005). Effect of cadmium on the growth of Chlamydomonas. Journal of Young Investigators 13: 416-420.

Awasthi M. \& Das D.N. (2005). Heavy metal stress on growth, photosynthesis and enzymatic activities of free and immobilized Chlorella vulgaris. Annals of Microbiology 55: 1-7.

Bajguz. A. (2011). Suppression of Chlorella vulgaris growth by cadmium, lead, and copper stress and its restoration by endogenous brassinolide. Archives of Environmental Contamination and Toxicology 60: 406-416.

Báscik-Remisiewicz A., Tomaszewska E., Labuda K. \& Tukaj Z. (2009). The effect of $\mathrm{Zn}$ and $\mathrm{Mn}$ on the toxicity of $\mathrm{Cd}$ to the green microalga Desmodemus armatus cultured at ambient and elevated (2\%) $\mathrm{CO}_{2}$ concentrations. Polish Journal of Environmental Studies 18: 775-780.

Bradford M.M. (1976). A rapid and sensitive method for the quantification of microgram quantities of protein utilizing the 
principle of protein-dye binding. Analytical Biochemistry 72: 248254.

Bräutigam A., Schaumlöffel D., Preud'homme H., Thondorf I. \& Dobritzsch D. (2011). Physiological characterization of cadmiumexposed Chlamydomonas reinhardtii. Plant, Cell and Environment 34: 2071-2082. doi: $10.1111 / \mathrm{j} .1365-$ 3040.2011.02404.x.

Carfagna S., Lanza N., Salbitani G., Basile A., Sorbo S. \& Vona V. (2013). Physiological and morphological responses of lead or cadmium exposed Chlorella sorokiniana 2118K (Chlorophyceae). SpringerPlus 2: 147 .

Carfagna S., Salbitani G., Vona V. \& Esposito S. (2011). Changes in cysteine and O-acetyl-L-serine levels in the microalga Chlorella sorokiniana in response to the Snutritional status. Journal of Plant Physiology 168: 2188-2195.

Chu K.H. \& Hashim M.A. (2007). Copper biosorption on immobilized seaweed biomass: Column breakthrough characteristics. Journal of Environmental Sciences 19: 928-932.

Dao L.H.T. \& Beardall J. (2016). Effects of lead on two green microalgae Chlorella and Scenedesmus: photosystem II activity and heterogeneity. Algal Research 16: 150-59.

Faraloni C. \& Torzillo G. (2017). Synthesis of Antioxidant Carotenoids in Microalgae. In D. Cvetkovic (Ed.), Response to Physiological Stress, Carotenoids (pp.143-157), InTech, doi: 10.5772/67843. Available from: https://www.intechopen.com/books /carotenoids/synthesis-of-

antioxidant-carotenoids-in-

microalgae-in-response-to-

physiological-stress (accessed

December 12, 2017).

Gao Z., Meng C., Gao H., Zhang X., Xu D., Su Y., Wang Y., Zhao Y. \& Ye N. (2013). Analysis of mRNA expression profiles of carotenogenesis and astaxanthin production of Haematococcus pluvialis under exogenous 2,4 epibrassinolide (EBR). Biological Research 46: 201-206.

Guedes A.C., Amaro H.M. \& Malcata F.X. (2011). Microalgae as source of carotenoids. Marine Drugs 9: 625644.

Jung H.B. (2017). Nutrients and heavy metals contamination in an urban estuary of northern New Jersey. Geosciences $\quad 7$ : 108. doi:10.3390/geosciences7040108

Kaplan, D. (2013). Absorption and Adsorption of Heavy Metals by Microalgae. In A. Richmond \& $\mathrm{Hu}$, Q (Eds.), Handbook of Microalgal Culture: Applied Phycology and Biotechnology (2 ${ }^{\text {nd }}$ Edition) (pp. 602-611), Oxford, U.K.: John Wiley \& Sons.

Kong I.C., Bitton G., Koopman B. \& Jung K.H. (1995). Heavy metal toxicity testing in environmental samples. Reviews of Environmental Contamination and Toxicology 142 : 119-147.

Kumar D., Santhanam P., Ananth S., Devi A.S., Nandakumar R., Prasath B.B., Jeyanthi S., Jayalakshmi T. \& Ananthi P. (2014). Effect of different dosages of zinc on the growth and biomass in five marine 
microalgae. International Journal of Fisheries and Aquaculture 6: 1-8.

Lemoine Y. \& Schoefs B. (2010). Secondary ketocarotenoid astaxanthin biosynthesis in algae: a multifunctional response to stress. Photosynthesis Research 106: 155177.

Li Y., Horsman M., Wu N., Lan C.Q. \& Dubois-Calero N. (2008a). Biofuels from microalgae. Biotechnology Progress 24: 815-820.

Li Y., Wang B., Wu N. \& Lan C.Q. (2008b). Effects of nitrogen sources on cell growth and lipid production of Neochloris oleoabundans. Applied Microbiology and Biotechnology 81: 629-636.

Mason L.H., Harp J.P. \& Han D.Y. (2014). $\mathrm{Pb}$

Neurotoxicity:

Neuropsychological Effects of Lead Toxicity. BioMed Research International 2014. http://dx.doi.org/10.1155/2014/840 547

Mata T.M., Martins A.A. \& Caetano N.S. (2009). Microalgae for biodiesel production and other applications: A review. Renewable and Sustainable Energy Reviews 14: 217-232.

McComb J., Alexander T.C., Han F.X. \& Tchounwou P.B. (2014). Understanding biogeochemical cycling of trace elements and heavy metals in estuarine ecosystems. Journal of Bioremediation \& Biodegradation 5: 1-6.

Mittler R. (2002). Oxidative stress, antioxidants and stress tolerance. Trends in Plant Science 7: 405-410.
Muwafq H.M. \& Bernd M. (2006). Toxicity of heavy metals on Scenedesmus quadricauda (Turp.) de Brebisson in batch cultures. Environmental Science and Pollution Research International 13: 98-104.

Neelam A. \& Rai L.C. (2003). Differential responses of three cyanobacteria to UV-B and Cd. Journal of Microbiology and Biotechnology 13: $544-551$.

Nriagu J.O. \& Pacyna J.M. (1988). Quantitative assessment of worldwide contamination of air, water and soils by trace metals. Nature 333: 134-139.

Nyholm N. \& Kallqvist T. (1989). Methods for growth inhibition toxicity tests with freshwater algae. Environmental Toxicology and Chemistry 8: 689.

Pandey A., Lee D.J., Chisti Y. \& Soccol C.R. (2013). Biofuel from Algae. U.K.: Elsevier.

Papanikolaou N.C., Hatzidaki E.G., Belivanis S., Tzanakakis G.N. \& Tsatsakis A.M. (2005). Lead toxicity update. A brief review. Medical Science Monitor 11: 329336.

Parsons T.R. \& Strickland J.D.H. (1963). Discussion of spectrophotometric determination of marine plant pigments, with revised equations for ascertaining chlorophylls and carotenoids. Journal of Marine Research 21: 115-163.

Penuelas J. \& Filella I. (2002). Metal pollution in Spanish terrestrial ecosystems during the twentieth century. Chemosphere 46: 501-505. 
Perales-Vela H.V., Pena-Castro J.M. \& Canizares-Villanueva R.O. (2006). Heavy metal detoxification in eukaryotic microalgae. Chemosphere 64: 1-10.

Pinto E., Sigaud-Kutner T.C.S., Leitao M.A.S., Okamoto O.K., Morse D. \& Colepicolo P. (2003). Heavy metalinduced oxidative stress in algae. Journal of Phycology 39: 10081018.

Priyadarshani I. \& Rath B. (2012). Commercial and industrial applications of micro algae - a review. Journal of Algal Biomass Utilization 3: 89-100.

Sander K. \& Murthy G.S. (2009, June 21). Enzymatic degradation of microalgal cell walls. Paper presented at the ASABE Annual International Meeting, Nevada, California.

Scheidegger C., Behra R. \& Sigg L. (2011). Phytochelatin formation kinetics and toxic effects in the freshwater alga Chlamydomonas reinhardtii upon short- and long-term exposure to lead(II). Aquatic Toxicology 101: 423-429.

Sears M.E. (2013). Chelation: Harnessing and enhancing heavy metal detoxification - a review. Scientific World Journal 2013 (12): 219840. doi: 10.1155/2013/219840

Shanab S., Essa A. \& Shalaby E. (2012). Bioremoval capacity of three heavy metals by some microalgae species (Egyptian isolates). Plant Signaling \& Behavior 7: 1-8.
Takaichi S. (2011). Carotenoids in algae: Distributions, biosyntheses and functions. Marine Drugs 9: 11011118.

USEPA (2003). United States Environmental Protection Agency Environment Report, www, EPA, gov/air/urban air/lead/what html. (accessed November 8, 2003).

Védrine C., Leclerc J.C., Durrieu C. \& Tran-Minh C. (2003). Optical whole-cell biosensor using Chlorella vulgaris designed for monitoring herbicides. Biosensors and Bioelectronics 18: 457-463.

Wang J. \& Chen C. (2009). Biosorbents for heavy metals removal and their future. Biotechnology Advances 27: 195-226.

Wang Z.S., Kong H.N. \& Wu D.Y. (2007). Acute and chronic copper toxicity to a saltwater cladoceran Moina monogolica Daday. Archives of Environmental Contamination and Toxicology 53: 50-56.

Yun H.J., Kim I., Kwon S.H., Kang J.S. \& Om A.S. (2011). Protective effect of Chorella vulgaris against leadinduced oxidative stress in rat brains. Journal of Health Science 57: 245-254.

Zhang W., Xiong B., Chen L., Lin K.F., Cui X.H., Bi H.S., Guo M.J. \& Wang W.L. (2013). Toxicity assessment of Chlorella vulgaris and Chlorella protothecoides following exposure to $\mathrm{Pb}(\mathrm{II})$. Environmental Toxicology and Pharmacology 36: 51-57. 